\title{
DEFINICJA BEZPIECZEŃSTWA SPOŁECZNEGO OKIEM PRAWNIKA - KRYTYCZNA PRÓBA USYSTEMATYZOWANIA POJĘĆ
}

\author{
„Naukę buduje się z faktów tak, jak dom buduje się \\ z cegieł, ale samo nagromadzenie faktów nie jest jesz- \\ cze nauką, podobnie jak kupa cegieł nie jest domem" \\ Jules Henri POINCAR ${ }^{1}$
}

Jean J. Rousseau rozważając teorię powstania Państwa, stanął na stanowisku, że powstało ono w wyniku umowy społecznej, która sprowadza się do następującego twierdzenia: „Każdy z nas społem oddaje swą osobę i całą swoją potęgę pod naczelne kierownictwo woli powszechnej i traktujemy każdego członka, jako część niepodzielną całości”. Wskazał on również cel tej umowy, jakim jest obrona i ochrona całego nowopowstałego społeczeństwa, jak i każdej osoby². Swym dziełem ten wybitny myśliciel okresu oświecenia, opierając się na dorobku filozofów starożytności, średniowiecza oraz oświecenia, pośrednio zwrócił uwagę na główne zadanie Państwa, jakim jest zapewnienie bezpieczeństwa i wolności każdemu obywatelowi. Interpretacja tego zadania, z biegiem lat, uległa ewolucji - od zapewnia wyłącznie pokoju do zagwarantowania dobrobytu poszczególnym członkom tej wspólnoty ${ }^{3}$. Przełomowy w tym zakresie okazał się XX i XXI w., gdy dokonano

Dr PAwel ZajĄC - adiunkt w Katedrze Prawa Cyberbezpieczeństwa i Nowych Technologii, Instytut Prawa, Akademia Sztuki Wojennej, Al. gen. A. Chruściela „Montera” 103, 00-910 WarszawaRembertów; e-mail: p.zajac@akademia.mil.pl; https://orcid.org/0000-0002-2188-5720

${ }^{1}$ Cyt. za: Mała księga cytatów, red. H. Lipiec, Radom: Oficyna Wydawnicza STON I 1994, s. 103.

2 J.J. Rousseau, Umowa społeczna, przekł. A. Peretiatkowicz, Poznań: Gebethner i Wolff 1920, s. 21.

${ }^{3}$ M. RukszTeŁŁo, Sprawiedliwość a bezpieczeństwo ekonomiczne obywateli, [w:] Wybrane aspekty bezpieczeństwa w zakresie działalności podmiotów stosunków międzynarodowych, red. P. Niwiński, M. Ilnicki, B. Woźniak-Krawczyk, Gdańsk: Instytut Politologii Uniwersytetu Gdańskiego 2015, s. 37. 
reorganizacji zadań Państwa i pojęcia bezpieczeństwa ${ }^{4}$. W jej wyniku, wyodrębniono wiele podkategorii i dziedzin bezpieczeństwa narodowego, podkreślając również obszar społeczny, który stał się pełnoprawnym przedmiotem badań nauk o bezpieczeństwie. W ten sposób powstała nauka o bezpieczeństwie społecznym, która związana jest ściśle z nowymi zadaniami, jakie spoczywają na Państwie.

Niniejszy artykuł ma na celu przedstawienie różnych koncepcji dotyczących istoty bezpieczeństwa społecznego oraz jego pojmowania we współczesnych naukach o bezpieczeństwie. Cel ten zostanie osiągnięty poprzez przegląd definicji pojęcia bezpieczeństwa społecznego zawartych zarówno w aktach normatywnych, jak i nomenklaturze, oraz ich wykładnię i interpretację w oparciu o metodę dogmatyczno-prawną oraz krytyczną analizę.

\section{PRZEGLĄD DEFINICJI POJĘCIA „BEZPIECZEŃSTWO SPOŁECZNE”}

Jednym z pierwszych prekursorów używania terminu bezpieczeństwo społeczne (social security) był amerykański uczony Isaac Max Rubinow, który utożsamiał ten termin z działaniami państwa wobec zagrożeń „czterech jeźdźców Apokalipsy” wypadków, chorób, starości oraz bezrobocia ${ }^{5}$. Po raz pierwszy, oficjalnie, użyto tego terminu w ustawodawstwie amerykańskim, w tytule ustawy - the Social Security Act of 1935, podpisanej przez Prezydenta F.D. Rossevelta w dniu 14 sierpnia 1935 r. $^{6}$ Pod pojęciem tym kryły się świadczenia, jakie Państwo miało wypłacać swoim obywatelom na wypadek starości, bezrobocia, inwalidztwa, śmierci oraz rodzicielstwa.

Jeden z autorów ustawy, senator Walter F. George, thumacząc projekt legislacyjny, stwierdził, że „Bezpieczeństwo społeczne nie jest jałmużną; to nie jest dobroczynność; to nie jest ulga [...]. Jest to zasłużone prawo, jednostka jest uprawniona do otrzymania korzyści z godności i szacunku dla samego siebie"7. Przyjmuje się jednak, że ideą całego programu była pomoc osobom starszym, których dotknęła recesja. Ustawa skierowana była do osób biednych i niezaradnych, którzy nie

\footnotetext{
${ }^{4}$ A. Skrabacz, Bezpieczeństwo społeczne. Podstawy teoretyczne i praktyczne, Warszawa: Dom Wydawniczy Elipsa 2012, s. 31.

${ }^{5}$ I.M. RuBinow, The Quest for Security, New York: Holt 1934. Wcześniej posługiwano się terminem ,polityka społeczna”, który odnosił się wyłącznie do kwestii robotniczych, a dopiero z czasem włączono do niego całość zagadnień związanych z zabezpieczeniem społecznym obywateli. RukszTelıo, Sprawiedliwość a bezpieczeństwo ekonomiczne obywateli, s. 37.

${ }^{6}$ The United States Statutes at Large, Year 1935, v. 49, s. 620-648.

7 "Social security is not a handout; it is not charity; it is not relief ... As an earned right, the individual is eligible to receive his benefit in dignity and self-respect". Cyt. za: D. KeLLeY, The History, Economics, and Philosophy of Social Security, [w:] https://atlassociety.org/commentary/ commentary-blog/4062-the-history-economics-and-philosophy-of-social-security [dostęp: 6.05.2017].
} 
zgromadzili odpowiedniej sumy kapitału, z którego mogliby pokrywać wydatki związane $\mathrm{z}$ podstawowymi potrzebami w okresie starości ${ }^{8}$.

Organizacja Narodów Zjednoczonych dostrzegając uniwersalność przesłania, jakie związane było z pojęciem bezpieczeństwa społecznego, implementowała ten termin do Powszechnej Deklaracji Prawa Człowieka z 1948 r. ${ }^{9}$, dokonując jego kodyfikacji na arenie międzynarodowej. Zgodnie z brzmieniem art. 22 tejże Deklaracji, „Każdy człowiek ma jako członek społeczeństwa prawo do ubezpieczeń społecznych [bezpieczeństwa społecznego - P.Z.]; ma również prawo do urzeczywistniania - poprzez wysiłek narodowy i współpracę międzynarodową oraz zgodnie $\mathrm{z}$ organizacją i zasobami każdego Państwa - swych praw gospodarczych, społecznych i kulturalnych, niezbędnych dla jego godności i swobodnego rozwoju jego osobowości”"10. Tym samym bezpieczeństwo społeczne zostało określone jako podstawowe prawo człowieka. Niedosyt pozostawia jednak brak wykładni tego prawa. Na problem ten zwróciła uwage jedna z agend ONZ - Międzynarodowa Organizacja Pracy, która podjęła się zadania „wtłoczenia” treści w termin „bezpieczeństwo społeczne”, czego rezultatem było przyjęcie następujących dokumentów: Konwencji C-070 dotyczącej bezpieczeństwa społecznego marynarzy ${ }^{11}$; Rezolucji C-102 o minimum bezpieczeństwa społecznego ${ }^{12}$; Konwencji C-118 dotyczącej równego traktowania ${ }^{13}$; Konwencji C-157 dotyczącej międzynarodowego systemu utrzymania prawa do bezpieczeństwa społecznego ${ }^{14}$.

${ }^{8}$ Tamże.

${ }^{9}$ Powszechna Deklaracja Prawa Człowieka uchwalona 10 grudnia 1948 r. przez Zgromadzenie Ogólne Narodów Zjednoczonych, [w:] http://www.ohchr.org/EN/UDHR/Pages/Language. aspx?LangID=pql [dostęp: 6.05.2017].

10 „Everyone, as a member of society, has the right to social security [wyróżnienie - P.Z.] and is entitled to realization, through national effort and international co-operation and in accordance with the organization and resources of each State, of the economic, social and cultural rights indispensable for his dignity and the free development of his personality". W polskim tekście dokonano błędnego thumaczenia terminu social security, który spłaszczony został wyłącznie do zabezpieczenia społecznego.

${ }^{11}$ International Labour Organisation, C070 - Social Security (Seafarers) Convention, 1946 (No. 70), Convention concerning Social Security for Seafarers, Adoption: Geneva, 28th ILC session (28 Jun 1946), [w:] http://www.ilo.org/dyn/normlex/en/f?p=NORMLEXPUB:12100:0::NO:12100 :P12100_INSTRUMENT_ID:312215:NO [dostęp: 6.05.2017].

12 International LABOUR Organisation, C-102 - Social Security (Minimum Standards) Convention, 1952 (No. 102) Convention concerning Minimum Standards of Social Security (Entry into force: 27 Apr 1955), [w:] http://www.ilo.org/dyn/normlex/en/f?p=NORMLEXPUB:12100:0::N O::P12100_INSTRUMENT_ID:312247 [dostęp: 6.05.2017].

${ }^{13}$ International Labour Organisation, C118 - Equality of Treatment (Social Security) Convention, 1962 (No. 118), Convention concerning Equality of Treatment of Nationals and NonNationals in Social Security (Entry into force: 25 Apr 1964), Adoption: Geneva, 46th ILC session (28 Jun 1962) [w:] https://www.ilo.org/dyn/normlex/en/f?p=NORMLEXPUB:12100:0::NO::P12100 ILO_CODE:C118 [dostęp: 6.05.2017].

${ }^{\overline{14}}$ International Labour Organisation, C157 - Maintenance of Social Security Rights Convention, 1982 (No. 157), Convention concerning the Establishment of an International System 
$\mathrm{Z}$ analizy powyższych aktów normatywnych wynika, że przez pojęcie bezpieczeństwa społecznego należy rozumieć: zabezpieczenie społeczne (system emerytalny); świadczenia ze strony Państwa na wypadek bezrobocia, inwalidztwa; pomoc społeczną; opiekę medyczną oraz szeroko pojmowane świadczenia rodzinne, a więc wszystkie aspekty życia człowieka, które zapewniają mu godziwe bytowanie i realizację podstawowego prawa człowieka, jakim jest prawo do życia i zdrowia. Państwo stało się tym samym benefaktorem świadczeń i programów pomocowych, dzięki którym powinny zostać zapewnione podstawowe środki do egzystencji dla osób, które z racji starości, niepełnosprawności bądź innej obiektywnej przesłanki, nie mogą same zadbać o swoje potrzeby.

$\mathrm{Na}$ gruncie polskiego porządku prawnego nie istnieje legalna definicja bezpieczeństwa społecznego. Termin ten powiązano jednak z jego pewnymi elementami, w szczególności zabezpieczeniem społecznym, które unormowane zostało przez ustrojodawcę w art. 67 Konstytucji Rzeczypospolitej Polskiej z 2 kwietnia 1997 r. ${ }^{15}$, zgodnie z którym: „1. Obywatel ma prawo do zabezpieczenia społecznego w razie niezdolności do pracy ze względu na chorobę lub inwalidztwo oraz po osiągnięciu wieku emerytalnego. Zakres i formy zabezpieczenia społecznego określa ustawa. 2. Obywatel pozostający bez pracy nie z własnej woli i nie mający innych środków utrzymania ma prawo do zabezpieczenia społecznego, którego zakres i formy określa ustawa”. Nie jest to jednak jedyne odwołanie do bezpieczeństwa społecznego, bowiem ustrojodawca reguluje tę materię pośrednio również w dalszych przepisach Konstytucji (art. 68 - ochrona zdrowia; art. 69 - pomoc osobom niepełnosprawnym; art. 70 - prawo do nauki; art. 71 - prawo rodziny do pomocy ze strony państwa; art. 72 - ochrona praw dziecka; art. 74 - bezpieczeństwo ekologiczne i ochrona środowiska; art. 75 - zaspokajanie potrzeb mieszkaniowych, art. 76 - ochrona konsumentów), których rozwinięcie znajduje się w aktach normatywnych rangi ustawowej i podustawowej.

Strategia Bezpieczeństwa Narodowego Rzeczypospolitej Polskiej ${ }^{16}$ podpisana przez Prezydenta Bronisława Komorowskiego w 2014 r., traktuje bezpieczeństwo społeczne jako podsystem bezpieczeństwa narodowego, składający się z takich dziedzin, jak: system ochrony dziedzictwa narodowego, instytucje edukacji dla

for the Maintenance of Rights in Social Security (Entry into force: 11 Sep 1986), Adoption: Geneva, 68th ILC session (21 Jun 1982), [w:] http://www.ilo.org/dyn/normlex/en/f?p=NORMLEXPUB:1210 0:0::NO:12100:P12100_INSTRUMENT_ID:312302:NO [dostęp: 6.05.2017].

${ }^{15}$ Dz. U. Nr 78, poz. 483 z późn. zm.

${ }^{16}$ Strategia Bezpieczeństwa Narodowego Rzeczypospolitej Polskiej, Warszawa 2014, [w:] https:// www.bbn.gov.pl /ftp/SBN\%20RP.pdf [dostęp: 7.05.2018], nr 139-144. 
bezpieczeństwa, media w systemie bezpieczeństwa narodowego, przeciwdziałanie systemom demograficznym i bezpieczeństwo socjalne ${ }^{17}$.

Dokonując zatem interpretacji celowościowej, należy uznać, że przyjęta przez Państwo Polskie koncepcja bezpieczeństwa społecznego odnosi się do zapewnienia swoim obywatelom warunków do godziwego życia, co przekłada się na rozwój duchowy i materialny całego Narodu ${ }^{18}$.

Powyższe rozumienie bezpieczeństwa społecznego ściśle związane jest z dorobkiem polskiej myśli naukowej, która jednak nie wypracowała jednej, wspólnej i całościowej definicji. Autorzy w swoich dziełach prezentują różne ujęcia jego postrzegania, często zbliżone do siebie. Dlatego też w celu lepszego zrozumienia omawianej kwestii należy dokonać przeglądu definicji pojęcia bezpieczeństwa społecznego, które można odnaleźć w polskiej literaturze przedmiotu, co pozwoli, na zrozumienie $\mathrm{w}$ dalszej części opracowania istoty tego zagadnienia.

M. Księżopolski w swoich rozważaniach dotyczących bezpieczeństwa społecznego zauważył, że jest ono związane z dwoma aspektami - wolnością od niedostatku materialnego oraz gwarancją rozwoju człowieka ${ }^{19}$. Podobnie uczyniła to B. Rysz-Kowalczyk według której obejmuje ono: „nie tylko stan wolności od ryzyk socjalnych, ale i od zagrożeń rozwoju psychospołecznego jednostki” ${ }^{20}$. Na aspekt rozwoju kładzie nacisk również A. Korcz, który stwierdził, że „bezpieczeństwem społecznym w kontekście rozważań o bezpieczeństwie narodowym można określić stan społeczeństwa zapewniający nie tylko trwanie oraz przetrwanie narodu, lecz również jego rozwój”21, oraz A. Skrabacz traktująca bezpieczeństwo społeczne jako składową bezpieczeństwa narodowego, oznaczającą „ochronę egzystencjalnych podstaw życia ludzi, zapewnienie możliwości zaspokajania indywidualnych potrzeb (materialnych i duchowych) oraz realizację aspiracji życiowych przez tworzenie warunków do pracy i nauki, ochronę zdrowia oraz gwarancje emerytalne"22. Na nieco inny wydźwięk bezpieczeństwa społecznego zwraca uwagę M. Leszczyński,

${ }^{17}$ W Strategii Bezpieczeństwa Narodowego Rzeczypospolitej Polskiej z 2007 r. termin bezpieczeństwo społeczne wiązano z takimi zagadnieniami, jak: praca i polityka społeczna; edukacja i nauka oraz aktywne i sprawne społeczeństwo, [w:] http://www.msz.gov.pl/resource/7d18e04d-8f234128-84b9-4f426346a112 [dostęp: 7.05.2018].

${ }^{18}$ Zob. J. Gierszewski, Bezpieczeństwo spoteczne jako dziedzina bezpieczeństwa narodowego, „Historia i Polityka” 23 (30) 2018, s. 24.

${ }^{19}$ M. Ksį̨żopolski, Bezpieczeństwo społeczne i jego zagrożenia, [w:] Polityka społeczna w okresie przemian, red. A. Piekara, J. Supińska, Warszawa: Państwowe Wydawnictwo Ekonomiczne 1985, s. 20.

${ }^{20}$ Leksykon polityki społecznej, red. B. Rysz-Kowalczyk, Warszawa: Oficyna Wydawnicza ASPRA-JR 2001, s. 20.

${ }^{21}$ A. Korcz, Bezpieczeństwo społeczne Rzeczypospolitej Polskiej, [w:] www.adamkorcz.w.interia. pl/spol.pdf. [dostęp: 4.11.2017].

${ }^{22}$ Skrabacz, Bezpieczeństwo spoleczne, s. 38 
według którego jest to „całokształt działań prawnych, organizacyjnych i wychowawczych realizowanych przez podmioty rządowe (narodowe i ponadnarodowe), pozarządowe oraz samych obywateli, które mają na celu zapewnienie pewnego poziomu życia osobom, rodzinom, grupom społecznym oraz niedopuszczenie do ich marginalizacji i wykluczenia społecznego" ${ }^{23}$.

A. Szymoniuk niejako łącząc powyższe koncepcje stwierdza, że bezpieczeństwo społeczne to „działania prawne, organizacyjne i realizowane przez instytucje rządowe, pozarządowe oraz samych obywateli, które mają na celu zapewnienie pewnego poziomu życia osobom, rodzinom, grupom społecznym oraz niedopuszczenie do ich marginalizacji i wykluczenia społecznego"24. Najszerszą i najgłębszą wykładnię pojęcia bezpieczeństwa społecznego zaprezentował J. Gierszewski, który dokonał krytycznej analizy definicyjnego pojmowania tej kwestii. Rozróżnił on bezpieczeństwo społeczne rozumiane jako wewnętrzną stabilność państwa istniejącą, ,dzięki systemowi umożliwiającemu zaspokajanie niezbędnych potrzeb bytu oraz swobodny rozwój społeczny na różnych poziomach organizacji państwa" od bezpieczeństwa społecznego w państwie, które zdefiniował jako: „zbiór przepisów i regulacji normatywno-prawnych różnej rangi organizujących system mający na celu zapewnienie obywatelom RP szeroko rozumianego bezpieczeństwa społecznego" zmierzającego do zaspokojenia istotnych potrzeb człowieka oraz ładu społecznego w państwie ${ }^{25}$.

\section{ISTOTA BEZPIECZEŃSTWA SPOŁECZNEGO}

Przegląd definicji bezpieczeństwa społecznego prowadzi do określenia jego istoty. $Z$ jednej strony będzie to zapewnienie bezpieczeństwa, rozumianego w jego klasycznej formie, a więc zabezpieczenie potrzeby: istnienia, przetrwania, pewności, stabilności, tożsamości, niezależności, ochrony poziomu życia i jakości życia ${ }^{26}$. W tym kontekście na bezpieczeństwo składają się dwa ściśle ze sobą powiązane pojęcia: stan odczuwania i proces, czyli określone działanie kompetentnych organów. Prowadzi on do zniwelowania zagrożeń, czyli pewnych zjawisk, które destrukcyjnie wpływają na stan odczuwania bezpieczeństwa przez jednostkę. A zatem bezpie-

\footnotetext{
${ }^{23}$ M. LeszcZyŃsKI, Bezpieczeństwo społeczne a bezpieczeństwo państwa, Kielce: Uniwersytet Humanistyczno-Przyrodniczy 2009, s. 37.

${ }^{24}$ A. Szymoniak, Organizacja i funkcjonowanie systemów bezpieczeństwa, Warszawa: Difin 2011, s. 160.

25 J. Gierszewski, Bezpieczeństwo społeczne. Studium z zakresu teorii bezpieczeństwa narodowego, Warszawa: Difin 2013, s. 173-174.

${ }^{26}$ E. NowaK, M. NowaK, Zarys teorii bezpieczeństwa narodowego, Warszawa: Difin 2011, s. 13.
} 
czeństwo to brak zagrożeń ${ }^{27}$, czyli stan „umożliwiający normalny rozwój państwa, pomyślną realizację wszystkich jego celów, uzyskiwaną zazwyczaj w wyniku zorganizowanej ochrony i obrony [...] przy użyciu sił i środków pochodzących ze wszystkich dziedzin działalności państwa"28. Jednak wyłącznie takie podejście staje się problematyczne, dlatego, że stan odczuwania jest kategorią subiektywną, niemierzalną. Każda jednostka inaczej odczuwa bezpieczeństwo. Konieczne zatem staje się ustandaryzowanie kryteriów odczuwania bezpieczeństwa i ich wyśrodkowanie. W tym celu należy dokonać klasyfikacji bezpieczeństwa na jego poszczególne systemy, które określą normy i standardy „stanu bezpieczeństwa”. W tej standaryzacji należy doszukiwać się celowości istnienia nauk o bezpieczeństwie.

$\mathrm{Z}$ drugiej strony, do istoty bezpieczeństwa społecznego należeć będzie rozwój jednostki, a przez to całego Narodu. W tym ujęciu zbiegają się ze sobą kompetencje państwa, grup społecznych oraz samych jednostek. Na państwie spoczywać będzie zadanie stworzenia takich warunków egzystencji swoich obywateli, dzięki którym będą oni mogli realizować swoje aspiracje życiowe. Związane to będzie z zapewnieniem tzw. minimalnego standardu życia, który określa granicę wydatków pozwalających na godziwy poziom egzystencji, a więc taki, w którym spełnione zostaną podstawowe potrzeby jednostek: żywność, odzież, mieszkanie, ochrona zdrowia, edukacja a także dostęp do środków łączności i transportu lokalnego ${ }^{29}$ a zatem wszystkie środki, które związane są z ochroną życia i zdrowia człowieka.

Kompetencje grup społecznych i indywidualnych jednostek powinny skupiać się na psychospołecznym aspekcie rozwoju, a zatem stworzeniu warunków akceptacji i tolerancji społecznej ${ }^{30}$. Dzięki nim jednostka będzie miała możliwość podążania za swoimi aspiracjami. Istotną rolę odgrywa tu również wychowanie, dzięki któremu człowiek jest władny odróżnić dobro od zła. Z kwestią tą związany jest system wartości, jaki powinien zostać przekazany dalszym pokoleniom tak, aby dążąc do swoich życiowych ideałów człowiek kierował się szacunkiem do innych osób realizując przy tym imperatyw kategoryczny Kanta.

Sprowadzając powyższe rozważania do zagadnienia bezpieczeństwa społecznego, w pierwszej kolejności należy stwierdzić, że dwie natury jego istoty - stan bez zagrożeń i rozwój człowieka, nie podlegają stopniowaniu. Oznacza to, że są nierozdzielne i przenikają się wzajemnie.

W doktrynie przez pojęcie zagrożenia społecznego rozumie się, „pewne procesy, zjawiska, sytuacje, problemy czy działania, które w konsekwencji utrudniają zrów-

${ }^{27}$ Tamże; P. Majer, A. URBAneK, Bezpieczeństwo społeczne. Ewolucja, instytucje, zagrożenia, Warszawa: Editions Spotkania 2016, s. 133.

28 J. Gierszewski, Bezpieczeństwo wewnętrzne. Zarys systemu, Warszawa: Difin 2013, s. 12.

${ }^{29}$ Zob. Skrabacz, Bezpieczeństwo spoteczne, s. 41.

${ }^{30}$ Tamże. 
noważony rozwój, dążenie do dobrobytu i wysokiej jakości życia poszczególnych członków i całego społeczeństwa"31. Wśród nich wymienia się w szczególności: przestępczość, ubóstwo i biedę, alkoholizm oraz bezrobocie ${ }^{32}$. Jednak obserwując dzisiejszą rzeczywistość należałoby dokonać rewizji niektórych z nich i skupić się na podstawowych procesach, z których wynikać mogą następne. Parafrazując stwierdzenie I.M. Rubinowa, zaczerpnięte z Biblii, o Czterech Jeźdźcach Apokalipsy zwiastujących koniec świata, można wskazać na współczesnych „posłańców”, do których zaliczyć należy: chciwość, korupcję, upadek obyczajów oraz egoizm. One stanowią bowiem główną bolączkę współczesnego świata i przyczyniają się do występowania takich procesów jak ubóstwo, bieda oraz bezrobocie.

W walkę z zagrożeniami społecznymi powinni zostać zaangażowani wszyscy, tj. państwo, pojmowane jako organ administracji publicznej, oraz społeczeństwo. Ze względu na charakterystyczną cechę, w jaką wyposażone jest państwo - możliwość zastosowania przymusu w celu respektowania określonych zasad, to na nim opierać się będzie stworzenie fundamentalnych programów przeciwdziałania zagrożeniom społecznym i określenie współpracy w jego realizacji z organizacjami pozarządowymi, grupami społecznymi i jednostkami. W tym celu wykorzystane powinny zostać wszelkiego rodzaju procesy poznawcze (analizowanie, identyfikowanie, przewidywanie); tworzenie pojęć; podejmowanie decyzji; organizowanie i rozwiązywanie problemów, również przy zastosowaniu mechanizmów i instrumentów prawnych, które będą zabezpieczały sprawiedliwą redystrybucje dóbr i usług oraz penalizowały zachowania odbiegające i szkodzące dobru społeczeństwa ${ }^{33}$. Kwestia sprawiedliwej redystrybucji uzależniona jest od przyjętej przez dane państwo polityki społecznej - począwszy od modelu marginalnego, skończywszy na modelu instytucjonalno-redystrybucyjnym ${ }^{34}$. Nie zmienia to jednak faktu, że w interesie każdej władzy pozostaje zagadnienie bezpieczeństwa i działalność zmierzająca do wyeliminowania wszelkiego rodzaju zagrożeń społecznych.

${ }^{31}$ Majer, Urbanek, Bezpieczeństwo społeczne, s. 135.

32 Szerzej zob. M. Kuś, O społecznym zagrożeniu bezpieczeństwa III RP, „Res Politicae” 5 (2013), s. 103-113.

${ }^{33}$ Por. W. Zubrzycki, Poznawcze aspekty zagrożeń, [w:] Bezpieczeństwo. Teoria - Badania - Praktyka, red. A. Czupryński, B. Wiśniewski, J. Zboina, Józefów: Wydawnictwo CNBOP-PIB 2015, s. 27-28.

${ }^{34}$ Wskazaną klasyfikację zaproponował R. Timuts. Zob. E. Karpowicz, Modele polityki społecznej. Kierunki zmian polityki społecznej w Polsce, „Informacje Biura Studiów i Ekspertyz” 1249 (2006), s. 4. 


\section{KRYTYCZNE UWAGI}

W opracowaniach dotyczących bezpieczeństwa społecznego często podkreśla się, że zdefiniowanie tego pojęcia jest zadaniem trudnym i karkołomnym, ze względu na „dynamizm procesów społecznych” oraz ewolucję państwa ${ }^{35}$. Przykładem tego mogą być wskazane powyżej próby znalezienia właściwego rozumienia tego sformułowania. Wielu wybitnych przedstawicieli świata nauki redefiniuje to pojęcie, wydobywa coraz to nowe treści, dokonuje kolejnych podziałów bezpieczeństwa społecznego, tworzy coraz bardziej rozbudowane i wyszukane pojęcia. W tym miejscu pojawia się pytanie o celowość takich działań. Badania naukowe ze swojej istoty powinny być nakierowane na poznanie i zrozumienie otaczającego nas świata, a przez to, na stworzenie mechanizmów i instrumentów, które dadzą się zastosować w praktyce, dzięki czemu możliwy będzie pełny rozwój człowieka. Obecnie nauka cechuje się zgoła odmiennym podejściem, w którym bardzo dużą rolę przykłada się do teoretycznej strony, przez co uprawianie badań naukowych staje się „sztuką dla sztuki”. Naukowcy tworzą coraz to bardziej rozbudowane definicje, które obarczone są zasadniczym mankamentem - ze względu na rozbudowaną treść, można je zastosować tylko do konkretnych przypadków. Należy zastanowić się zatem, czy nie lepszym rozwiązaniem byłoby wypracowanie jednej uniwersalnej definicji bezpieczeństwa społecznego, cechującej się abstrakcyjnością i generalnością na wzór przepisów prawa. Takie działanie pozwoliłoby na skupienie się na istocie tego zagadnienia, czyli praktycznym przełożeniu nauki na rzeczywistość. W tym zakresie można wzorować się na naukach ścisłych, w których występują pewne stałe pojęcia, dzięki którym cały wysiłek naukowy skupia się na dalszym rozwoju nauki, a nie nieustannym tworzeniu definicji. Idąc tym tropem i podejmując przyczynek do dalszej dyskusji naukowej w tym zakresie, można zaproponować nowe rozumienie bezpieczeństwa społecznego, które oparłoby się zmianom zachodzącym w społeczeństwach i państwach. W tym celu należy skupić się na istocie bezpieczeństwa społecznego, którym jest zniwelowanie zagrożeń i zapewnienie rozwoju człowieka, bowiem te wartości zawsze pozostaną niezmienne. Stąd, podejmując próbę nowego podejścia do bezpieczeństwa społecznego, można przyjąć, że są to wszelkie przejawy działalności państwa, społeczeństwa i jednostek zmierzające do zapewnia prawidłowego i zrównoważonego rozwoju człowieka poprzez zlikwidowanie procesów, zjawisk i czynników utrudniających jego osiągnięcie. Takie szerokie podejście pozwoli na wtłoczenie w ramy bezpieczeństwa społecznego wszelkich zagadnień i kwestii, które dotyczą niezmąconego funkcjonowania człowieka w społeczeństwie - dostępu do żywności, mieszkania,

${ }^{35}$ Majer, UrbaneK, Bezpieczeństwo społeczne, s. 64. 
ubrań, medycyny oraz edukacji, a więc środków gwarantujących realizację prawa do życia i zdrowia. Powyższą definicję można zastosować we wszystkich modelach polityki społecznej, jakie zostały przyjęte przez poszczególne państwa, dzięki czemu bezpieczeństwo społeczne stałoby się dziedziną uniwersalną oraz interdyscyplinarną. Bowiem kwestie związane z ochroną podstawowych praw człowieka, leżą w gestii wszystkich Narodów. Połączenie wysiłków naukowców z całego świata, pozwoli na wypracowanie najlepszych instrumentów zapewnienia człowiekowi rozwoju, w myśl słów L. Pasteura: „Nauka nie ma żadnej ojczyzny, gdyż wiedza ludzka obejmuje cały świat" ${ }^{36}$. W tych właśnie cechach należy doszukiwać się sukcesu nauki o bezpieczeństwie społecznym i jej praktycznego przełożenia na życie.

\section{BIBLIOGRAFIA}

\section{ŹRÓDŁA PRAWA}

Konstytucja Rzeczypospolitej Polskiej z dnia 2 kwietnia 1997 r., Dz. U. Nr 78, poz. 483 z późn. zm. The Social Security Act of 1935, „The United States Statutes at Large” Year 1935, v. 49, s. 620-648. Powszechna Deklaracja Prawa Człowieka uchwalona 10 grudnia 1948 r. przez Zgromadzenie Ogólne

Narodów Zjednoczonych, [w:] http://www.ohchr.org/EN/UDHR/Pages/Language.aspx?LangID=pql [dostęp: 6.05.2017].

InTERnATIONAL LABOUR ORGANiSATION, C070 - Social Security (Seafarers) Convention, 1946 (No.

70), Convention concerning Social Security for Seafarers, Adoption: Geneva, 28th ILC session (28 Jun 1946), [w:] http://www.ilo.org/dyn/normlex/en/f?p=NORMLEXPUB:12100:0::NO:1210 0:P12100_INSTRUENT_ID:312215:NO [dostęp: 6.05.2017].

International Labour Organisation, C-102 - Social Security (Minimum Standards) Convention, 1952 (No. 102) Convention concerning Minimum Standards of Social Security (Entry into force: 27 Apr 1955), [w:] http://www.ilo.org/dyn/normlex/en/f?p=NORMLEXPUB:12100:0::NO: :P12100_INSTRU MENT_ID:312247 [dostęp: 6.05.2017].

InTERnational Labour Organisation, C118 - Equality of Treatment (Social Security) Convention, 1962 (No. 118), Convention concerning Equality of Treatment of Nationals and Non-Nationals in Social Security (Entry into force: 25 Apr 1964), Adoption: Geneva, 46th ILC session (28 Jun 1962), [w:] https://www.ilo.org/dyn/normlex/en/f?p=NORMLEXPUB:12100:0::NO::P12100_ILO_ CODE:C118 [dostęp: 6.05.2017 r.].

International Labour Organisation, C157 - Maintenance of Social Security Rights Convention, 1982 (No. 157), Convention concerning the Establishment of an International System for the Maintenance of Rights in Social Security (Entry into force: 11 Sep 1986), Adoption: Geneva, 68th ILC session (21 Jun 1982), http://www.ilo.org/dyn/normlex/en/f?p=NORMLEXPUB:12100 :0::NO:12100: P12100_INSTRUMENT_ID:312302:NO [dostęp: 6.05.2017].

${ }^{36}$ Discours d'inauguration de l'Institut Pasteur, [w:] https://archive.org/stream/b22301720/ b22301720_djvu.txt [dostęp: 14.05.2018]. 


\section{LITERATURA}

Discours d]inauguration de l'Institut Pasteur, 1988, [w:] https://archive.org/stream/b22301720/ b22301720_djvu.txt [dostęp: 14.05.2018].

GierszewsKi Janusz: Bezpieczeństwo społeczne jako dziedzina bezpieczeństwa narodowego, Historia i Polityka 23 (30) 2018, s. 21-38.

Gierszewski Janusz: Bezpieczeństwo społeczne. Studium z zakresu teorii bezpieczeństwa narodowego, Warszawa: Difin 2013.

GieRszewski Janusz: Bezpieczeństwo wewnętrzne. Zarys systemu, Warszawa: Difin 2013.

KarPowicz Ewa: Modele polityki społecznej. Kierunki zmian polityki społecznej w Polsce, Informacje Biura Studiów i Ekspertyz 1249 (2006), s. 3-12.

Kelley David: The History, Economics, and Philosophy of Social Security, 2010, [w:] https:// atlassociety.org/commentary/commentary-blog/4062-the-history-economics-and-philosophy-of-social-security [dostęp: 6.05.2017].

Korcz Adam: Bezpieczeństwo społeczne Rzeczypospolitej Polskiej, 2012, [w:] www. adamkorcz.w.interia.pl/spol.pdf. [dostęp: 4.11.2017].

KsIĘżOPOLSKI Mirosław: Bezpieczeństwo społeczne i jego zagrożenia, [w:] Polityka społeczna w okresie przemian, red. A. Piekara, J. Supińska, Warszawa: Państwowe Wydawnictwo Ekonomiczne 1985, s. 18-24.

Kuś Małgorzata: O społecznym zagrożeniu bezpieczeństwa III RP, Res Politicae 5 (2013), s. 103-113.

Leksykon polityki społecznej, red. B. Rysz-Kowalczyk, Warszawa: Oficyna Wydawnicza ASPRA-JR 2004.

LESZCZYŃSKI Marek: Bezpieczeństwo społeczne a bezpieczeństwo państwa, Kielce: Uniwersytet Humanistyczno-Przyrodniczy 2009.

Majer Piotr, Urbanek Andrzej: Bezpieczeństwo społeczne. Ewolucja, instytucje, zagrożenia, Warszawa: Editions Spotkania 2016.

Mała księga cytatów, red. H. Lipiec, Radom: Oficyna Wydawnicza STON I 1994.

Nowak Eugeniusz, NowaK Maciej: Zarys teorii bezpieczeństwa narodowego, Warszawa: Difin 2011.

Rousseau Jean J.: Umowa społeczna, przekł. A. Peretiatkowicz, Poznań: Gebethner i Wolff 1929.

RuBinow Isaac M. The Quest for Security, New York: Holt 1934.

RukszTelıo Monika: Sprawiedliwość a bezpieczeństwo ekonomiczne obywateli, [w:] Wybrane aspekty bezpieczeństwa $\mathrm{w}$ zakresie działalności podmiotów stosunków międzynarodowych, red. P. Niwiński, M. Ilnicki, B. Woźniak-Krawczyk, Gdańsk: Instytut Politologii Uniwersytetu Gdańskiego 2015, s. 34-42.

Skrabacz Aleksandra: Bezpieczeństwo społeczne. Podstawy teoretyczne i praktyczne, Warszawa: Dom Wydawniczy Elipsa 2012.

Strategia Bezpieczeństwa Narodowego Rzeczypospolitej Polskiej, Warszawa 2007, [w:] http://www. msz.gov.pl/resource/7d18e04d-8f23-4128-84b9-4f426346al12 [dostęp: 7.05.2018].

Strategia Bezpieczeństwa Narodowego Rzeczypospolitej Polskiej, Warszawa 2014, [w:] https://www. bbn.gov.pl /ftp/SBN\%20RP.pdf [dostęp: 7.05.2018].

SzYMONIAK Andrzej: Organizacja i funkcjonowanie systemów bezpieczeństwa, Warszawa: Difin 2011.

ZubrzyCKi Waldemar: Poznawcze aspekty zagrożeń, [w:] Bezpieczeństwo. Teoria - Badania Praktyka, red. A. Czupryński, B. Wiśniewski, J. Zboina, Józefów: Wydawnictwo CNBOP-PIB 2015, s. 25-34. 


\title{
DEFINICJA BEZPIECZEŃSTWA SPOŁECZNEGO OKIEM PRAWNIKA - KRYTYCZNA PRÓBA USYSTEMATYZOWANIA POJĘĆ
}

\author{
Streszczenie
}

Bezpieczeństwo społeczne, jako element bezpieczeństwa narodowego, stanowi z punktu widzenia organów administracji publicznej jeden z istotnych czynników wyznaczających kierunek polityki wewnętrznej państwa. Dlatego też na przestrzeni wieków podejmowano liczne próby stworzenia definicji bezpieczeństwa społecznego, wtłaczając w jej ramy co raz to nowe elementy. Pokłosiem takiego działania jest brak jednej, komplementarnej definicji pojęcia, która satysfakcjonowałaby wszystkich przedstawicieli zarówno świata nauki, jak i polityki.

Niniejszy artykuł ma celu ukazanie wybranych koncepcji bezpieczeństwa społecznego wraz ze wskazaniem jego istoty i natury oraz poddanie ich krytycznej analizie. Autor powyższym zabiegiem chce rozpocząć dyskusję dotyczącą uniwersalizacji pojęć i definicji związanych z bezpieczeństwem społecznym.

Słowa kluczowe: zabezpieczenie społeczne; terminologia; polityka społeczna; nauki o bezpieczeństwie; bezpieczeństwo narodowe

\section{LEGAL PERSPECTIVE OF SOCIAL SECURITY DEFINITION - CRITICAL ANALYSIS}

\section{Su m mary}

From the point of view of public administration bodies, social security, as an element of national security, is one of the important factors determining the direction of the internal policy of the state. That is why over the centuries numerous attempts have been made to create a definition of social security, including new elements within it. The result of such action is the lack of one complementary definition of the concept that would satisfy all representatives of both the world of science and politics.

This article aims to show selected concepts of social security along with an indication of its essence and nature and subjecting them to critical analysis. The author of the above procedure wants to start a discussion on the universalization of concepts and definitions related to social security.

Key words: social security; terminology; social policy; security science; national security 